\title{
POVEZANOST KVALITETA ŽIVOTA I DEPRESIVNIH OBELEŽJA KOD PACIJENATA NA HEMODIJALIZNOM TRETMANU'
}

\author{
Vojislava Bugarski ${ }^{2}$, Mikloš Biro i Zdenka Novović \\ Odsek za psihologiju, Filozofski fakultet Novi Sad
}

Istraživanje je sprovedeno $u$ cilju ispitivanja povezanosti različitih aspekata kvaliteta života sa pojavom depresivnosti medu pacijentima sa hroničnom bubrežnom insuficijencijom na hemodijaliznom tretmanu. Istraživanje je sprovedeno na uzorku od 93 ispitanika, oba pola, uzrasta od 24 do 78 godina. Svi ispitanici su usled terminalnog stadijuma bubrežne insuficijencije bili podvrgnuti hemodijaliznom tretmanu. Konstrukt kvaliteta života pacijenata na hemodijaliznom tretmanu je operacionalizovan preko 80 - ajtemske Kratke skale za ispitivanje kvaliteta života $i$ bubrežne bolesti (KDQOL), dok je pojava depresivnosti operacionalno definisana sumacionim skorom na Bekovoj skali za ispitivanje depresivnosti. Kratka skala za ispitivanje kvaliteta života i bubrežne bolesti (KDQOL) sadrži 19 supskala koje mere različite aspekte kvaliteta života. U cilju što ilustrativnijeg prikaza povezanosti kvaliteta života i pojave depresivnosti, početni broj supskala je redukovan na tri osnovna domena kvaliteta života, pri čemu je svaki od domena predstavljen preko faktorskih skorova prve glavne komponente. Prve glavne komponente su imenovane kao Fizički aspekti kvaliteta života, Emocionalno-socijalni aspekti kvaliteta života $i$ Lična percepcija bolesti. Višestrukom regresionom analizom ispitivana je povezanost ova tri aspekta kvaliteta života na pojavu depresivnosti. Ustanovljeno je da je sa pojavom depresivnosti povezano lošije postignuće u domenu Emocionalno-socijalni aspekti kvaliteta života $i$ lošije postignuće u domenu Lična percepcija bolesti.

Ključne reči: hemodijaliza, kvalitet života, depresivnost

\footnotetext{
${ }^{1}$ Rad u okviru projekta "Psihološke karakteristike društva u tranziciji“ (br. 149008), koji se realizuje pod pokroviteljstvom Ministarstva za nauku i tehnološki razvoj Republike Srbije

2 e-mail: vbugarski@eunet.rs
} 


\section{Uvod}

Procena kvaliteta života hronično obolelih osoba sve više dobija na značaju u istraživanjima tokom poslednjih godina, prvenstveno jer hronična bolest, sa svojim fizičkim i psihosocijalnim obeležjima, ima neizbežan i često negativan uticaj na kvalitet života obolele osobe (Sathvik, Parthasarathi, Narahari \& Gurudev, 2008). Značaj procene kvaliteta života kod pacijenata u terminalnom stadijumu bubrežne insuficijencije na hemodijaliznom tretmanu posebno pobuđuje pažnju istraživača, jer je reč o kompleksnom fenomenu, čija je procena otežana složenom interakcijom negativnih posledica osnovne bolesti, pozitivnih aspekata hemodijaliznog tretmana, ali istovremeno i ograničavajućeg režima koji ovakav tretman zahteva. Definisanje pojma kvaliteta života i dalje predstavlja teškoće za istraživače usled svoje kompleksnosti i specifičnosti, pri čemu još uvek ne postoji jednoglasno rešenje o sadržini samog pojma (Cella, 1994). U stručnoj literaturi pojam kvaliteta života uglavnom se vezuje za pojam zdravlja, pri čemu se smatra da ovi koncepti međusobno utiču jedan na drugi i da su veoma bliski. To bi značilo da određenje pojma zdravlja u značajnoj meri određuje i pojam kvaliteta života (Valderrabano, Jofre \& Lopez-Gomez, 2001). Prema definiciji Svetske zdravstvene organizacije, zdravlje se definiše kao "stanje potpunog fizičkog, socijalnog i psihičkog blagostanja, koje podrazumeva odsustvo nesposobnosti i simptoma, uz opšte dobro stanje" (Kaplan \& Toshima, 1990). Stoga, kada se govori o kvalitetu života, neizbežno se kao polazna osnova koriste određeni aspekti definicije zdravlja. Obično se ističe da kvalitet života obuhvata fizičke, psihološke i socijalne aspekte zdravlja, pri čemu se svaki od datih domena sastoji iz više različitih komponenti (Slika 1).

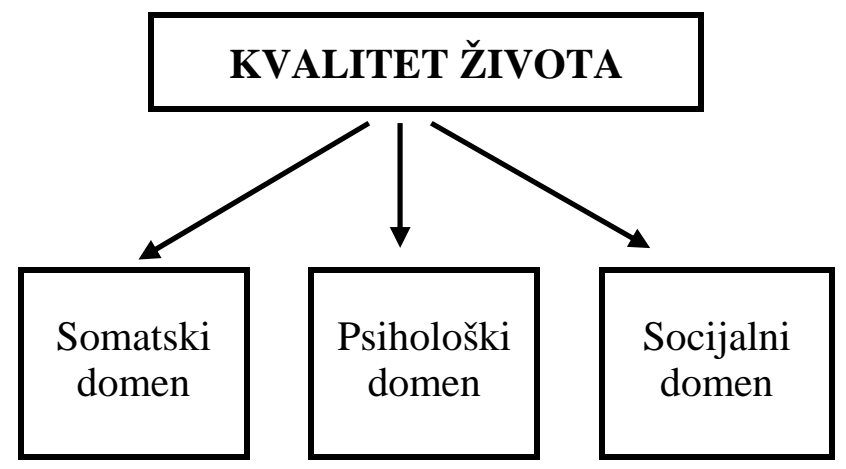

Slika 1 Domeni kvaliteta života 
Svaka od datih komponenti može biti izražena na različite načine u zavisnosti od subjektivnog doživljaja pojedinačne osobe, što posledično rezultira u različitim procenama kvaliteta života. Na primer, dva pacijenta koji imaju slične terapijske i kliničke uslove mogu proceniti kvalitet svog života na različite načine, a data procena je rezultat interakcije između pacijentovih životnih okolnosti i načina na koji su date okolnosti doživljene od strane pacijenta (Apolone \& Mosconi, 1998, prema Valderrabano et al., 2001).

Kada je reč o proceni kvaliteta života kod pacijenata sa terminalnim stadijumom bubrežne insuficijencije na hemodijaliznom tretmanu, bitno je istaći da postepenom progresijom bubrežne disfunkcije, pacijenti počinju da se sreću sa mnoštvom simptoma koji postepeno utiču na svakodnevni život. Kako vreme protiče, uticaj bolesti na funkcionalni status i kvalitet života, postaje sve izraženiji. Terapijske metode za zamenu bubrežne funkcije delimično otklanjaju date simptome, ali dovode i do značajnih promena u životnom stilu pacijenta. Date promene takođe mogu značajno da utiču na kvalitet života. Bubrežni pacijenti, u poređenju sa kontrolnom grupom zdravih vršnjaka, ostvaruju znatno niže postignuće na upitnicima za procenu kvaliteta života, naročito u domenu fizičkog funkcionisanja, dok su razlike bile manje izražene u oblasti psihičkog funkcionisanja (Mingardi et al., 1999, prema Valderrabano et al., 2001).

Brojne studije su ustanovile mnoštvo faktora koji mogu uticati na pad kvaliteta života među dijaliziranim pacijentima. Stariji uzrast pacijenata je bio značajno povezan sa propadanjem u oblasti fizičkog funkcionisanja (Moreno et al., 1996, prema Valderrabano et al., 2001; Perneger, Leski, Chopard-Stoermann \& Martin, 2003), dok je ustanovljena povezanost između mlađeg uzrasta i lošijeg postignuća u psihološko/duhovnom domenu kvaliteta života (Welch \& Austin, 1999, prema Valderrabano et al., 2001; Vázquez et al., 2003). Ustanovljeno je da žene ostvaruju znatno niža postignuća u svim ispitivanim domenima kvaliteta života u odnosu na muškarce, i to u periodu pre početka dijaliznog tretmana (Harris, Luft, Rudy \& Tierny, 1993), tokom dijaliznog tretmana (Mingardi et al., 1999, prema Valderrabano et al., 2001), kao i nakon uspešne transplantacije bubrega (Simmons \& Abress, 1990). Ustanovljeno je i da su komorbiditet, ženski pol, nezaposlenost, nizak edukativni nivo i mali prihodi povezani sa lošijim kvalitetom života (Hariss et al., 1993). Anemija, jedan od učestalih pratilaca hronične bubrežne insuficijencije, pokazala se kao faktor koji ima najizraženiji negativan uticaj na kvalitet života (Gerson et al., 2004). Negativni uticaj anemije manifestovao se na kvalitet života pacijenata i pre nego što su počeli sa dijaliznim tretmanom, ali i tokom samog dijaliznog tretmana (Valderrabano, 1996). Značaj socijalnih faktora 
takođe može biti od presudnog značaja za kvalitet života. Nezaposlenost, nizak nivo edukacije i niski prihodi značajno utiču na pad kvaliteta života (Harris et al., 1993). Neizbežno je istaći i značaj određenih aspekata kvaliteta života u predikciji morbiditeta i mortaliteta (Mapes et al., 1999). Nizak nivo socijalne podrške, nepridržavanje zahteva dijaliznog režima i izražena negativna percepcija efekata bolesti, nezavisno su povezane sa povišenom stopom mortaliteta (Kimmel, Thamer \& Richard, 1998). Svakako ne treba zanemariti činjenicu, da pored do sada navedenih faktora, kvalitet života pacijenta određuju i etnička pripadnost, faza razvoja hronične bubrežne insuficijencije, modalitet dijalizne terapije, fizička aktivnost u vidu vežbi, poremećaj sna, bol, erektilna disfunkcija, pacijentovo zadovoljstvo negom, opterećenje simptomima i percepcija težine bolesti (Han et al., 2002; Parker, Kutner, Bliwise, Bailey \& Rye, 2003; Rosas et al., 2003; Kimmel \& Patel, 2006).

Pored svih do sada navedenih faktora koji utiču na pad kvaliteta života, posebna pažnja se pridaje depresivnosti, koja se poslednjih godina u istraživanjima izdvaja kao veoma značajan prediktor pada kvaliteta života. Depresija ima značajan uticaj na kvalitet života kod pacijenata i pre početka dijaliznog tretmana (Shidler, Peterson \& Kimmel, 1998), ali i tokom dijaliznog tretmana (Kimmel, Weihs \& Peterson, 1993). Novija istraživanja potvrđuju pozitivnu vezu između depresivne simptomatologije i morbiditeta (Kutner, Brogan, Hall, Haber \& Daniels, 2000), doživljenog kvaliteta života (Mollaoglu, 2004), kao i stope smrtnosti među pacijentima na hemodijaliznom tretmanu (Gavard et al., 1993; Burton et al., 1986; Peterson et al., 1991, prema Kimmel et al., 1998). Depresija koja prati hroničnu bubrežnu insuficijenciju u značajnoj meri može komplikovati tok same hronične bolesti (Kimmel et al., 1993; Kimmel, 2001) i često može biti znatno otpornija na tretman (Kimmel et al., 1993; Kimmel, 2001; Kimmel, 2002, prema Kimmel \& Peterson, 2005; Keitner et al., 1991, Klein et al., 1988, prema Kimmel et al., 1998). Kao ilustracija može poslužiti podatak da je među pacijentima iznad 65 godina života, sa hroničnom bubrežnom insuficijencijom, stepen hospitalizacije usled dijagnoze depresije znatno viši u poređenju sa pacijentima sa drugim hroničnim oboljenjima, kao što su ishemijska bolest srca, cerebrovaskularne bolesti i peptični ulkus (Kimmel et al., 1998). Takođe, pacijenti sa depresivnim poremećajem na dijaliznom tretmanu, pokazuju veću otpornost na terapijski efekat, što uslovljava potencijalno slabiji ishod, lošiju prognozu i manju stopu preživljavanja (Kimmel et al., 1998). Treba istaći da većina istraživanja ispituje odnos između kvaliteta života i depresivnosti na način gde se depresivnost posmatra kao prediktor pada kvaliteta života, ali se sve češće postavlja pitanje među istraživačima u kojoj meri je kvalitet života pacijenata na hemodijaliznom tretmanu zapravo prediktor pojave depresivnih obeležja, odnosno u 
kojoj meri su ove dve pojave povezane (Son, Choi, Park, Bae \& Lee 2009). Rukovođeni ovom istraživačkom pretpostavkom, autori rada su kao osnovni cilj istraživanja postavili ispitivanje povezanosti različitih domena kvaliteta života i pojave depresivnih obeležja među domaćim pacijentima na hemodijaliznom tretmanu. Kao dodatni cilj istraživači su postavili proveru pretpostavljene trofaktorske strukture instrumenta koji je korišćen $u$ istraživanju u cilju procene kvaliteta života na domaćem uzorku pacijenata na hemodijaliznom tretmanu. Reč je o tri faktora, koje su autori datog rada nazvali domen Fizičkih aspekata kvaliteta života, domen Emocionalno-socijalnih aspekata kvaliteta života i domen Lična percepcija bolesti.

\section{Metod}

\section{Uzorak}

Istraživanje je sprovedeno u periodu od novembra 2004. godine do decembra 2005. godine, na uzorku od 98 ispitanika, oba pola (53 muškarca i 40 žena), uzrasta od 24 do 78 godina. Od navedenog broja, pet ispitanika nije adekvatno ispunilo upitnike, stoga nisu bili uključeni u dalju analizu, tako da je konačna statistička analiza ispitanog uzorka i dobijenih rezultata rađena na 93 ispitanika. Svi ispitanici su pripadali grupi koja je usled nastanka terminalnog stadijuma hronične bubrežne insuficijencije morala biti podvrgnuta hemodijaliznom tretmanu. Upravo je dijagnoza terminalnog stadijuma hronične bubrežne insuficijencije, koja podrazumeva podvrgavanje hemodijaliznom tretmanu, predstavljala osnovni kriterijum na osnovu koga su ispitanici bili uključeni $\mathrm{u}$ istraživanje. Kriterijumi isključivanja iz istraživanja su bili prisustvo grubog kognitivnog deficita i primena antidepresivne farmakoterapije usled postojeće dijagnoze depresivnog poremećaja. Ispitivanje se odvijalo tokom boravka ispitanika u Centru za hemodijalizu, Klinike za kliničku imunologiju i nefrologiju, Instituta za interne bolesti, Kliničkog centra Vojvodina u Novom Sadu. Režim hemodijaliznog tretmana podrazumevao je učestalost dolazaka ispitanika dva ili tri puta nedeljno, u trajanju od po četiri sata. Poštujući etičke zahteve, svi ispitanici bili su upoznati sa osnovnim ciljevima istraživanja i informacijom da će dobijeni podaci biti korišćeni isključivo u naučne svrhe, kao i da se garantuje anonimnost svih dobijenih podataka i identiteta ispitanika. Svi ispitanici su dali svoju pismenu saglasnost za učešće $\mathrm{u}$ datom istraživanju. Za ispitanike koji su izveštavali o fizičkim ograničenjima (npr. slabovidost, uključen dijalizni aparat na ruku kojom piše i sl.), koja su ih onemogućavala da na adekvatan način popune upitnike, bila je obezbeđena stručna pomoć (od strane ispitivača) u cilju uspešnog ispunjavanja upitnika. 


\section{Instrumenti}

1. Bekova skala depresivnosti (Beck, Ward, Mendelson, Mock \& Erbaugh, 1961) - predstavlja jednodimenzionalnu skalu za procenu depresivnih obeležja, koja u istraživanjima zauzima značajno mesto zbog svoje pouzdanosti i validnosti. Sastoji se od 21 pitanja sa mogućnošću gradiranja odgovora na četvorostepenoj skali od 0 do 3 , pri čemu više vrednosti na ponuđenoj skali podrazumevaju prisustvo intenzivnije izraženih depresivnih simptoma. Ukupni skor se izračunava jednostavnim sabiranjem svih odgovora dobijenih na dvadeset i jednoj tvrdnji, a vrednosti ukupnog skora se kreću od 0 do 63, pri čemu viši ukupni skor ukazuje na izraženije prisustvo depresivnih obeležja. Intenzitet depresivnih obeležja se može kvantifikovati određivanjem jednog od ponuđena četiri stepena depresivnosti. Granični skor za prisustvo klinički značajnih depresivnih obeležja predstavlja 10 bodova. Skala nije standardizovana na domaćoj populaciji. Pokazatelj pouzdanosti skale ispitan na domaćem uzorku ispitanika sa hroničnom bubrežnom insuficijencijom iznosi: Cronbachova $\alpha=, 901$.

Usled teorijske pretpostavke o jednodimenzionalnosti predmeta merenja izvršena je faktorizacija Bekove skale depresivnosti. Korišćena je analiza glavnih komponenata. Izdvojeno je pet faktora čiji karakteristični koreni imaju vrednost veću od 1 . Ovaj broj faktora objašnjava $65,44 \%$ ukupne varijanse (Tabela 1).

Tabela 1. Karakteristični koreni i procenat objašnjene varijanse

\begin{tabular}{llll}
\hline Komponente & $\begin{array}{l}\text { Karakteristični } \\
\text { koren }\end{array}$ & $\begin{array}{l}\text { Procenat } \\
\text { varijanse }\end{array}$ & $\begin{array}{l}\text { Kumulativni } \\
\text { procenat }\end{array}$ \\
\hline 1 & 7.636 & 36.360 & 36.360 \\
2 & 2.342 & 11.151 & 47.511 \\
3 & 1.478 & 7.037 & 54.549 \\
4 & 1.217 & 5.794 & 60.343 \\
5 & 1.072 & 5.106 & 65.449 \\
\hline
\end{tabular}

Za razliku od datog Gutman-Kajzerovog kriterijuma za izbor broja faktora, grafički metod koji je predložio Katel daje predlog za dva faktora (Grafik 1). 


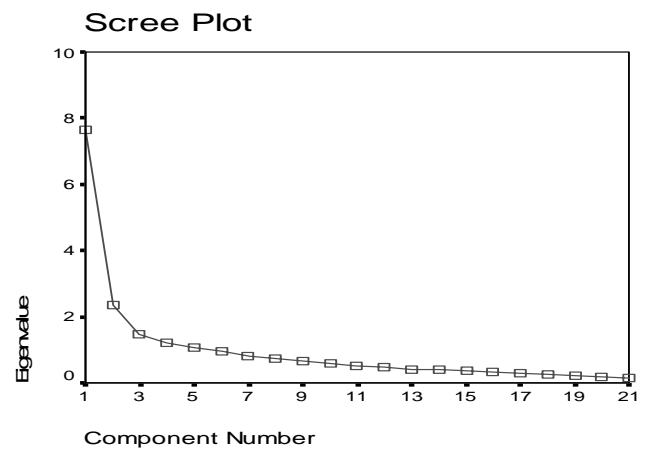

Grafik 1. Scree dijagram

Međutim, usled pretpostavke o jednodimenzionalnosti predmeta merenja i najvećeg procenta objašnjene varijanse prvim izolovanim faktorom (36,36\%), autori su se odlučili da u daljoj analizi zadrže izolovanu prvu glavnu komponentu. Izolovani faktor je zbog svog sadržaja naslovljen kao Depresivnost. Korelacija stavki sa izolovanim faktorom i komunaliteti dati su u Prilogu 1.

2. Kratka forma upitnika o kvalitetu života $i$ bubrežnoj bolesti (KDQOL) (Hays et al., 1997) je jedan od najučestalije korišćenih samoopisnih upitnika konstruisan posebno za pacijente sa bubrežnom bolešću i za one koji se usled iste nalaze na dijaliznom tretmanu. Dati upitnik ukupno sadrži 80 ajtema, od kojih se 43 ajtema odnose na različite aspekte bubrežne insuficijencije i čine 8 supskala: simptomi bolesti, efekti bubrežne bolesti na dnevni život, teret bubrežne bolesti, radni status, kognitivna funkcija, kvalitet socijalnih interakcija, seksualna funkcija i san, uz dodatne 3 skale koje se odnose na kvalitet života socijalna podrška, uticaj osoblja sa dijaliznog tretmana i pacijentovo zadovoljstvo istim.

Pored navedena 43 ajtema, upitnik sadrži i još dodatnih 36 ajtema, koji ispituju sveukupni zdravstveni status, i čine dodatnih 8 supskala: fizičko funkcionisanje, ograničenja uslovljena fizičkim zdravstvenim problemima, ograničenja uslovljena emocionalnim zdravstvenim problemima, socijalno funkcionisanje, emocionalno blagostanje, bol, energija/umor, i percepcija opšteg zdravstvenog stanja.

Originalna verzija upitnika je uz dozvolu autora prevedena na srpski jezik. Upitnik zbog svog obima nije predstavljen $u$ radu, ali ga autori ovog rada mogu proslediti na zahtev zainteresovanih. Upitnik nije standardizovan na domaćem uzorku. Pregled pokazatelja pouzdanosti svih supskala, dobijenih na 
domaćem uzorku ispitanika sa hroničnom bubrežnom insuficijencijom, prikazan je u Tabeli 2 .

Pouzdanost supskale Zadovoljstvo pacijenta negom nije mogla biti izračunata, jer data supskala sadrži jedan ajtem. Koeficijenti pouzdanosti su zadovoljavajući za većinu primenjenih supskala.

Tabela 2. Originalni indikatori pouzdanosti svih supskala iz Kratke forme upitnika o kvalitetu života i bubrežnoj bolesti (KDQOL)

\begin{tabular}{ll}
\hline Ime supskale & Cronbachova \\
& $a$ \\
\hline 1. Simptomi/problemi & .87 \\
2. Efekti bubrežne bolesti & .77 \\
3. Opterećenje bubrežnom bolešću & .82 \\
4. Radna sposobnost & .69 \\
5. Kognitivna funkcija & .43 \\
6. Kvalitet socijalnih interakcija & .45 \\
7. Kvalitet sna & .73 \\
8. Socijalna podrška & .73 \\
9. Podrška od strane osoblja na dijalizi & .90 \\
10. Seksualna funkcija & .95 \\
11. Fizičko funkcionisanje & .88 \\
12. Ograničenje uzrokovanofizičkim problemima & .77 \\
13. Ograničenje uzrokovano emocionalnim problemima & .91 \\
14. Socijalna funkcija & .76 \\
15. Emocionalno blagostanje & .78 \\
16. Bol & .82 \\
17. Energija/zamor & .82 \\
18. Opšte zdravlje & .61 \\
\hline
\end{tabular}




\section{Rezultati}

Radi što jasnijeg prikaza povezanosti između određenih aspekata kvaliteta života i prisustva depresivnih obeležja, autori rada su odlučili da prvo u skladu sa određenim teorijskim pretpostavkama u datoj oblasti ukupan broj supskala sa Kratke forme upitnika o kvalitetu života $i$ bubrežne bolesti redukuju na tri tzv. domena kvaliteta života (Valderrabano et al., 2001). To su domen Fizičkih aspekata kvaliteta života, domen Emocionalno-socijalnih aspekata kvaliteta života i domen Lična percepcija bolesti.

- domen Fizičkih aspekata kvaliteta života čine sledeće supskale simptomi/problemi, radni status, kognitivna funkcija, san, ograničenja uslovljena fizičkim zdravstvenim problemima, fizičko funkcionisanje, bol, energija/umor;

- domen Emocionalno-socijalnih aspekata kvaliteta života čine sledeće supskale - emocionalno blagostanje, socijalna funkcija, kvalitet socijalnih interakcija, ograničenja uslovljena emotivnim problemima, socijalna podrška;

- domen Lična percepcija bolesti čine sledeće supskale - efekti bubrežne bolesti na svakodnevni život, teret bubrežne bolesti, opšta percepcija zdravlja.

\section{Faktorska analiza domena Fizički aspekti kvaliteta života}

Faktorizacijom domena Fizički aspekti kvaliteta života izdvojen je jedan faktor čiji karakteristični koren ima vrednost veću od 1 i koji objašnjava 47,72\% ukupne varijanse. Korišćena je analiza glavnih komponenata. Karakteristični koren i obuhvat varijanse predstavljeni su u Tabeli 3.

Tabela 3. Karakteristični koren i procenat objašnjene varijanse

\begin{tabular}{cccc}
\hline Komponente & $\begin{array}{c}\text { Karakteristični } \\
\text { koren }(\lambda)\end{array}$ & $\begin{array}{c}\text { Procenat } \\
\text { varijanse }\end{array}$ & $\begin{array}{c}\text { Kumulativni } \\
\text { procenat }\end{array}$ \\
\hline 1. & 3.818 & 47.727 & 47.727 \\
\hline
\end{tabular}

S obzirom na teorijsku pretpostavku o jednodimenzionalnosti datog domena i izolovanu prvu glavnu komponentu, koja objašnjava najveći procenat varijanse, prihvaćen je predlog o izdvajanju prvog faktora koji je nazvan Fizički aspekti kvaliteta života. Korelacija supskala sa izolovanim faktorom, 
njihov sadržaj i komunaliteti dati su u Tabeli 4. Pored Gutman-Kajzerovog kriterijuma za izbor broja faktora na svakoj supskali, korišćen je i grafički metod koji je predložio Katel, ali zbog uštede prostora neće biti prikazan u radu.

Tabela 4. Matrica strukture prve glavne komponente $i$ komunaliteti domena Fizički aspekti bolesti

\begin{tabular}{lcl}
\hline \multicolumn{1}{c}{ Naziv supskale } & $\mathrm{r}$ & $\mathrm{h}^{2}$ \\
\hline Simptomi i problemi & .755 & .570 \\
Fizičko funkcionisanje (+ dobro) & -.700 & .491 \\
Ograničenje zbog fizičkih problema & -.651 & .424 \\
(+ ne postoji ograničenje) & & \\
Bol (+ viši) & .744 & .553 \\
Energija/zamor (+ viši umor) & .814 & .663 \\
Radni status (+ zaposlen) & -.388 & .151 \\
Kognitivna funkcija (-) & .697 & .486 \\
Kvalitet sna (+ dobar) & -.694 & .481 \\
\hline
\end{tabular}

\section{Faktorska analiza domena Emocionalno-socijalni aspekti kvaliteta života}

Faktorizacijom domena Emocionalno-socijalni aspekti kvaliteta života izdvojen je jedan faktor čiji karakteristični koren ima vrednost veću od 1 i objašnjava 51,29\% ukupne varijanse. Korišćena je analiza glavnih komponenata. Karakteristični koren i obuhvat varijanse predstavljeni su u Tabeli 5.

Tabela 5. Karakteristični koren i procenat objašnjene varijanse

\begin{tabular}{cccc}
\hline Komponente & $\begin{array}{c}\text { Karakteristični } \\
\text { koren }(\lambda)\end{array}$ & $\begin{array}{c}\text { Procenat } \\
\text { varijanse }\end{array}$ & $\begin{array}{c}\text { Kumulativni } \\
\text { procenat }\end{array}$ \\
\hline 1. & 2.565 & 51.292 & 51.292 \\
\hline
\end{tabular}

S obzirom na teorijsku pretpostavku o jednodimenzionalnosti datog domena i najvećim procentom objašnjene varijanse prvom glavnom komponentom, prihvaćen je predlog o izdvajanju prvog faktora koji je nazvan Emocionalnosocijalni aspekti kvaliteta života. Korelacija supskala sa izolovanim faktorom, 
njihov sadržaj i komunaliteti dati su u Tabeli 6. Pored Gutman-Kajzerovog kriterijuma za izbor broja faktora na svakoj supskali, korišćen je i grafički metod koji je predložio Katel, ali zbog uštede prostora neće biti prikazan u radu.

Tabela 6. Matrica strukture prve glavne komponente i komunaliteti domena Emocionalnosocijalni aspekti bolesti

\begin{tabular}{lcc}
\hline \multicolumn{1}{c}{ Naziv supskale } & \multicolumn{2}{c}{$\mathrm{h}^{2}$} \\
\hline Emocionalno blagostanje & .885 & .783 \\
Socijalno funkcionisanje & & \\
(+ ima problema) & -.829 & .688 \\
Kvalitet socijalnih interakcija (-) & -.769 & .592 \\
Ograničenje zbog emocionalnih & & \\
problema (+ ne postoji ograničenje) & .616 & .380 \\
Socijalna podrška (+ viša) & .350 & .123 \\
\hline
\end{tabular}

\section{Faktorska analiza domena lična percepcija bolesti}

Faktorizacijom domena Lična percepcija bolesti izdvojen je jedan faktor čiji karakteristični koren ima vrednost veću od 1 i objašnjava 68,37\% ukupne varijanse. Korišćena je metoda glavnih komponenata. Karakteristični koren i obuhvat varijanse predstavljeni su u Tabeli 7.

Tabela 7. Karakteristični koren i procenat objašnjene varijanse

\begin{tabular}{cccc}
\hline Komponente & $\begin{array}{c}\text { Karakteristični } \\
\text { koren }\end{array}$ & $\begin{array}{c}\text { Procenat } \\
\text { varijanse }\end{array}$ & $\begin{array}{c}\text { Kumulativni } \\
\text { procenat }\end{array}$ \\
\hline 1. & 2.051 & 68.378 & 68.378 \\
\hline
\end{tabular}

S obzirom na teorijsku pretpostavku o jednodimenzionalnosti datog domena i najveći procenat objašnjene varijanse prvom glavnom komponentom, prihvaćen je predlog o izdvajanju prvog faktora koji je nazvan Lična percepcija bolesti. Korelacija subskala sa izolovanim faktorom, njihov sadržaj i komunaliteti dati su u Tabeli 8. Pored Gutman-Kajzerovog kriterijuma za izbor broja faktora na svakoj supskali, korišćen je i grafički metod koji je predložio Katel, ali zbog uštede prostora neće biti prikazan. 
Tabela 8. Matrica strukture prve glavne komponente i komunaliteti domena Lična percepcija bolesti

\begin{tabular}{lcc}
\hline \multicolumn{1}{c}{ Naziv supskale } & $\mathrm{r}$ & $\mathrm{h}^{2}$ \\
\hline Opšta percepcija zdravlja & & \\
(+ slabije zdravlje) & .859 & .737 \\
Teret bubrežne bolesti (-) & -.837 & .701 \\
Efekti bubrežne bolesti na svakodnevni život & .783 & .613 \\
\hline
\end{tabular}

Dalje $\mathrm{u}$ analizama, povezanost između pojave depresivnosti i tri domena kvaliteta života testirana je putem višestruke regresione analize (Tabela 9). Kriterijumska, odnosno zavisna varijabla, operacionalno je definisana preko faktorskog skora prve glavne komponente dobijene na Bekovoj skali depresivnosti, dok su prediktorske varijable operacionalno definisane faktorskim skorovima dobijenim na prvim glavnim komponentama svakog od tri domena kvaliteta života. Viši skorovi u domenu Lična percepcija označavaju lošiju percepciju bolesti od strane obolelog.

Tabela 9. Koeficijent multiple korelacije i parcijalni doprinosi prediktora

\begin{tabular}{|c|c|c|c|}
\hline \multirow{2}{*}{$\begin{array}{l}\text { Kriterijumska varijabla } \\
\text { Prediktorske varijable: }\end{array}$} & \multicolumn{3}{|c|}{ Depresivnost $\quad \mathrm{R}=.742, \mathbf{p}<.001$} \\
\hline & 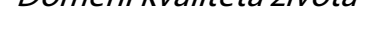 & $p$ & $\beta$ \\
\hline \multicolumn{2}{|l|}{ Intercept } & & 1 \\
\hline \multicolumn{2}{|c|}{ Fizički aspekti kvaliteta života } & 0.121 & 0.398 \\
\hline \multicolumn{2}{|c|}{ Emocionalno-socijalni aspekti kvaliteta života } & -0.383 & 0.001 \\
\hline \multicolumn{2}{|c|}{ Aspekt lične percepcije bolesti (-) } & 0.323 & 0.005 \\
\hline
\end{tabular}

Analiza rezultata ukazuje da je ceo regresioni model značajan, pri čemu vrednost koeficijenta multiple korelacije ukazuje na visok intenzitet povezanosti prediktorskog skupa sa kriterijumskom varijablom. U odnosu na pojavu depresivnosti, kao značajni parcijalni prediktori se izdvajaju domen emocionalno-socijalni aspekti kvaliteta života i lična percepcija bolesti. Lošije postignuće u domenu emocionalno-socijalni aspekti kvaliteta života i lošije postignuće u domenu lična percepcija bolesti povezano je sa pojavom depresivnosti. 


\section{Diskusija}

Rezultati istraživanja ukazuju da je lošije postignuće u određenim domenima kvaliteta života pacijenata na hemodijaliznom tretmanu značajno povezano sa pojavom depresivnosti. Ustanovljeno je da su od tri ispitana domena kvaliteta života, dva značajno povezana sa pojavom depresivnosti. Reč je o lošijem postignuću u oblasti emocionalno-socijalnih aspekata kvaliteta života, kao i o negativnoj percepciji bolesti. Značaj povezanosti između kvaliteta života i depresivnosti među osobama sa hroničnim oboljenjima više puta je potvrđena (Peyrot \& Rubin, 1997; Mancuso, Peterson \& Charlson, 2000). Emocionalnosocijalni domen kvaliteta života odnosi se na kvalitet, vrstu i učestalost socijalnih interakcija, kao i na pokazatelje emocionalnog statusa koji prati osnovno oboljenje $u$ vidu povišene napetosti i straha koji se obično vezuje za doživljaj neizvesnosti hroničnog oboljenja. Potencijalno objašnjenje odnosilo bi se na pretpostavku da hemodijalizni tretman podrazumeva prisustvo neizbežne anticipacije smrtnog ishoda, pri čemu dati osećaj neizvesnosti utiče i na prisustvo česte napetosti, praćene hroničnim nezadovoljstvom, uslovljenim drastičnim promenama u zdravstvenom statusu, stilu života i socijalnim interakcijama, što se posledično odražava na emocionalni status. Rezultati dobijeni u datom istraživanju potvrđuju nalaze ranijih istraživanja (Brett, 1999).

Drugi domen kvaliteta života koji se pokazao značajno povezan sa pojavom depresivnosti odnosi se na lošiju percepciju bolesti od strane samog pacijenta. Značaj koji osoba pripisuje samoj bolesti je kompleksna pojava višefaktorski uslovljena, jer zavisi od mnoštva činilaca od kojih bismo kao najznačajnije mogli izdvojiti obeležja ličnosti, težinu oboljenja, sociokulturni kontekst, komorbiditet, funkcionalnu osposobljenost, ekonomski status i socijalnu podršku. Procena svih navedenih činilaca od strane obolele osobe utiče na formiranje stava prema osnovnoj bolesti, koji se posledično ispoljava na razne načine i u različitim domenima. Ranija istraživanja su, usled značaja ovog aspekta kvaliteta života, ukazala svojim nalazima na potvrdu navedenih pretpostavki. Značaj koji osoba pripisuje samom oboljenju, ustanovljen je kao ključni faktor za pridržavanje sa zahtevima dijaliznog režima (Christensen, Wiebe, Edwards, Michels \& Lawton, 1996; Christensen, 2000), sa pojavom depresivnosti i lošijim kvalitetom života, što se registruje već i u početnim fazama bubrežne insuficijencije (Sacks, Peterson \& Kimmel, 1990; Shidler et al., 1998; Jadoulle, Hoyois \& Jadoul, 2005). Ranija istraživanja ustanovila su kako je doživljaj pacijenta da bolest ima manje negativnih efekata pozitivno korelirao sa većim stepenom ostvarene socijalne podrške i nižim nivoom stresa (Kaveh \& Kimmel, 2001). Među ispitanim uzorkom, ustanovljeno je da 
što je doživljaj bolesti lošiji, prisustvo depresivnih obeležja je izraženije, što navodi kliničare na primenu određene strategije $u$ tretmanu pacijenata na hemodijaliznom tretmanu. U cilju kreiranja što pozitivnije slike bolesti od strane pacijenta, na raspolaganju se nalazi više opcija. Prva bi se odnosila na pretpostavku da bolja informisanost pacijenata, par meseci pre početka samog hemodijaliznog tretmana, o prirodi same bolesti, prednostima i posledicama hemodijaliznog tretmana, realnim očekivanjima u smislu funkcionalne osposobljenosti, može dovesti do znatno boljeg doživljaja same bolesti, a samim tim i manje stope depresivnosti među ovim pacijentima kada se već počne sa hemodijaliznim tretmanom. Ovakva strategija omogućava pacijentima da se barem delimično pripreme na ograničenja i zahteve koji ih očekuju, a samim tim ublažava intenzitet negativnih emocija sa kojima se pacijenti često susreću na početku hemodijaliznog tretmana. Određena istraživanja su već potvrdila ove pretpostavke (White, Pilkey, Lam \& Holland, 2002). Takođe se kao mogućnost javlja opcija da se pacijenti delimično obmanjuju od strane stručnog osoblja o prirodi i posledicama same bolesti, radi kreiranja što pozitivnijeg doživljaja bolesti. No, ovakav stav nosi sa sobom izvesnu etičku dilemu i stoga bi zahtevao ozbiljnije razmatranje prednosti i nedostataka ovakve mogućnosti. Kao poslednja opcija svakako je ona koja je i najzastupljenija, a to je informisanje pacijenata o svim aspektima bolesti i samom tretmanu, što pacijent obično saznaje kada hemodijalizni tretman već počne, što može značajno uticati na formiranje negativnog doživljaja o bolesti, usled nemogućnosti anticipacije pozitivnog ishoda, kao posledice nepripremljenosti pacijenta na mnoštvo negativnih aspekata hemodijaliznog tretmana koji su iznenada nastupili.

Na samom kraju, treba svakako istaći da dato istraživanje ima izvesna ograničenja, pri čemu se prvenstveno misli na transferzalnu prirodu istraživanja koja onemogućava preciznije rasvetljavanje prirode veze između različitih aspekata kvaliteta života, sa jedne strane i pojave depresivnosti, sa druge strane. U tom kontekstu preporuka za buduća istraživanja sa istim ciljem bi se odnosila na longitudinalno praćenje kvaliteta života i depresivnosti pacijenata na hemodijaliznom tretmanu, gde bi se tokom više uzastopnih merenja pratili nivoi depresivnosti i kvaliteta života. 


\section{Reference}

Beck, A. T., Ward, C. H., Mendelson, M., Mock, J. \& Erbaugh, J. (1961). An inventory for measuring depression. Archives of General Psychiatry, 4, 561 571.

Brett, M. C. (1999). Predictors of depression in hemodialysis patients: social/cognitive variables and adequacy of dialysis (Doctoral dissertation, University of Miami, 1999). Dissertation Abstracts International-B, 60/06.

Cella, D. F. (1994). Quality of life: concepts and definition. Journal of Pain and Symptom Managment, 9, 186-192.

Christensen, A. J. (2000). Patient-by-treatment context interaction in chronic disease: A conceptual framework for the study of patient adherence. Psychosomatic Medicine, 62, 435-443.

Christensen, A. J., Wiebe, J. S., Edwards, D. L., Michels, J. D., \& Lawton, W. J. (1996). Body consciousness, illness-related impairment, and patient adherence in hemodialysis. Journal of Consulting and Clinical Psychology, $64,147-152$.

Gerson, A., Hwang, W., Fiorenza, J., Barth, K., Kaskel, F., Weiss, L., Zelikovsky, N., Fivush, B. \& Furth, S. (2004). Anemia and health related quality of life in adolescents with chronic kidney disease. American Journal of Kidney Diseases, 44, 1017-1023.

Han, J. S., Yoon, J. W., Jo, S. K., Shin, J. H., Shin, C., Lee, J. B., Cha, D. R., Cho, W. Y., Pyo, H. J., Kim, H. K., Lee, K. B., Kim, H., Kim, K. W., Kim, Y. S., Lee, J. H., Park, S. E., Kim, C.S., Wea, K. S., Oh, K. S., Chung, T. S. \& Suh, S. Y. (2002). Insomnia in diabetic hemodialysis patients prevalence and risk factors by a multicenter study. Nephron, 92, 127-132.

Harris, B., Luft, F. C., Rudy, D. W. \& Tierny, W. M. (1993). Clinical correlation of functional status in patients with chronic renal insufficiency. American Journal of Kidney Diseases, 21, 161-166.

Hays R. D., Kallich, J. D., Mapes, D. L., Coons, S. J., Amin, N., Carter, W. B. \& Kamberg, C. (1997). Kidney Disease Quality of Life-Short Form (KDQOLSF) Version 1.3 - Manual for Use and Scoring. Retrieved October 23, 2004 from: http://www.gim.med.ucla.edu/kdqol/index.htm

Jadoulle, V., Hoyois, P. \& Jadoul, M. (2005). Anxiety and depression in chronic hemodialysis: some somatopsychic determinants. Clinical Nephrology, 63, 113-118. 
Kaplan, R. M. \& Toshima, M. T. (1990). The functional effects of social relationships on chronic illnesses and disability. U Sarason, B.R. et al. (eds.) Social support: An interactional view. New York: Wiley-Interscience.

Kaveh, K. \& Kimmel, P. L. (2001). Compliance in hemodialysis patients: multidimensional measures in search of a gold standard. American Journal of Kidney Diseases, 36, 244-266.

Kimmel, P. L. (2001). Psychosocial factors in dialysis patients. Kidney International, 59, 1599-1613.

Kimmel, P. L. \& Patel, S. S. (2006). Quality of life in patients with chronic kidney disease: focus on end-stage renal disease treated with hemodialysis. Seminars in Nephrology, 26, 68-79.

Kimmel, P. L. \& Peterson, R. A. (2005). Depression in end-stage renal disease patients treated with hemodialysis: tools, correlates, outcomes, and needs. Seminars in Dialysis, 18, 91-97.

Kimmel, P. L., Thamer, M. \& Richard, C. (1998). Psychiatric ilness in patients with end-stage renal disease. The American Journal of Medicine, 105, 214221.

Kimmel, P. L., Weihs, K. \& Peterson, R. A. (1993). Survival in hemodialysis patients: The role of depression. Journal of the American Society of Nephrology, 4, 12-27.

Kutner, N. G., Brogan, D., Hall, W. D., Haber, M. \& Daniels, D. S. (2000). Functional impairment, depression, and life satisfaction among older hemodialysis patients and age-matched controls: A prospective study. Archives of Physical Medicine and Rehabilitation, 81, 453-459.

Mancuso, C. A., Peterson, M. G. E. \& Charlson, M. E. (2000). Effects of depressive symptoms on health-related quality of life in asthma patients. Journal of General and Internal Medicine, 15, 301-310.

Mapes, D. L., McCullough, K. P., Meredith, D., Locatelli, F., Valderrabano, F. \& Held, P. J. (1999). Quality of life predicts mortality and hospitalization for hemodialysis patients in the US and Europe. Journal of the American Society of Nephrology, 10, 249A.

Mollaoglu, M. (2004). Depression and health-related quality of life in hemodialysis patients. Dialysis \& Transplantation, 33, 544-549. 
Parker, K. P., Kutner, N. G., Bliwise, B. L., Bailey, J. L. \& Rye, D. B. (2003). Nocturnal sleep, daytime sleepiness, and quality of life in stable patients on hemodialysis. Health and Quality of Life Outcomes, 1, 68-75.

Perneger, T. V., Leski, M., Chopard-Stoermann, C. \& Martin, P. Y. (2003). Assessment of health status in chronic hemodialysis patients. Journal of nephrology, 16, 252-259.

Peyrot, M. \& Rubin, R. R. (1997). Levels and risks of depression and anxiety symptomatology among diabetic adults. Diabetes Care, 20, 585 -590.

Rosas, S. E., Joffe, M., Franklin, E., Strom, B. L., Kotzker, W., Brensinger, C., Grossman, E., Glasser, D. B. \& Feldman, H. I. (2003). Association of decreased quality of life and erectile dysfunction in hemodialysis patients. Kidney International, 64, 232-238.

Sacks, C. R., Peterson, R. A. \& Kimmel, P. L. (1990). Perception of illness and depression in chronic renal disease. American Journal of Kidney Diseases, 15, 31-39.

Sathvik, B. S., Parthasarathi, G., Narahari, M. G. \& Gurudev, K. C. (2008). An assessment of the quality of life in hemodialysis patients using the WHOQOL-BREF questionnaire. Indian Journal of Nephrology, 18, 141149.

Shidler, N. R., Peterson, R. A. \& Kimmel, P. L. (1998). Quality of life and psychosocial relationships in patients with chronic renal insufficiency. American Journal of Kidney Diseases, 32, 557-566.

Simmons, R. G. \& Abress, L. (1990). Quality of life issues for end-stage renal disease patients. American Journal of Kidney Diseases, 15, 201-208.

Son, Y. J., Choi, K. S., Park, Y. R, Bae, J. S. \& Lee, J. B. (2009). Depression, Symptoms and the Quality of Life in Patients on Hemodialysis for EndStage Renal Disease. American Journal of Nephrology, 29, 36-42.

Valderrabano, F. (1996). Erythropoietin in chronic renal failure. Kidney International, 50, 1373-1391.

Valderrabano, F., Jofre, R. \& Lopez-Gomez, J. M. (2001). Quality of life in end-stage renal disease patients. American Journal of Kidney Diseases, 38, 443-464.

Vázquez, I., Valderrábano, F., Jofré, R., Fort, J., López-Gómez, J. M., Moreno, F. \& Sanz-Guajardo, D. (2003). Psychosocial factors and quality of life in 
young hemodialysis patients with low comorbidity. Journal of nephrology, 16, 886-894.

White, C. A., Pilkey, R. M., Lam, M. \& Holland, D. C. (2002). Pre-dialysis clinic attendance improves quality of life among hemodialysis patients. $B M C$ Nephrology, $3,3$. 


\section{Prilog}

Prilog 1. Matrica strukture prve glavne komponente na Bekovoj skali depresivnosti $i$ Komunaliteti

\begin{tabular}{|c|c|c|}
\hline $\begin{array}{l}\text { Broj stavke na } \\
\text { Bekovoj skali } \\
\text { depresivnosti }\end{array}$ & $\begin{array}{c}\text { r sa } \\
\text { PGK Bekove skale }\end{array}$ & $\mathrm{h}^{2}$ \\
\hline BDI_1 & .782 & .611 \\
\hline BDI_2 & .642 & .412 \\
\hline BDI_3 & .592 & .350 \\
\hline BDI_4 & .774 & .599 \\
\hline BDI_5 & .409 & .167 \\
\hline BDI_6 & .551 & .304 \\
\hline BDI_7 & .685 & .469 \\
\hline BDI_8 & .676 & .457 \\
\hline BDI_9 & .497 & .247 \\
\hline BDI_10 & .654 & .428 \\
\hline BDI_11 & .734 & .538 \\
\hline BDI_12 & .393 & .155 \\
\hline BDI_13 & .699 & .489 \\
\hline BDI_14 & .629 & .395 \\
\hline BDI_15 & .569 & .324 \\
\hline BDI_16 & .533 & .284 \\
\hline BDI_17 & .596 & .355 \\
\hline BDI_18 & .522 & .273 \\
\hline BDI_19 & .223 & .050 \\
\hline BDI_20 & .671 & .450 \\
\hline BDI_21 & .527 & .278 \\
\hline
\end{tabular}




\title{
ABSTRACT
}

\section{RELATIONS BETWEEN THE QUALITY OF LIFE AND DEPRESSIVE CHARACTERISTICS IN PATIENTS ON HAEMODIALYSIS}

\author{
Vojislava Bugarski, Mikloš Biro, and Zdenka Novović
}

An objective of this research was to evaluate the association between different aspects of the quality of life and depression among chronic renal failure patients on haemodialysis. The study comprised 93 patients of both sexes, aged 24 to 78 years, who were undergoing haemodialysis due to terminal stage renal insufficiency. The quality of life was measured using the 80-item Kidney Disease Quality of Life (KDQOL) questionnaire, while depression was defined using the total scores on the Beck Depression Inventory. The 80-item KDQOL consists of 18 subscales measuring different aspects of quality of life. In order to represent the relationship between the quality of life and occurrence of depression as illustrative as possible, the original number of the subscales was reduced to the three main areas of quality of life, each represented by factorial scores for their first principal components. The first components were named as follows: physical aspects of quality of life, emotional-social aspects, and perception of illness. The correlations between these three areas and the occurrence of depression were analysed using multiple regression analysis. It was found that the occurrence of depression was associated with poorer performances in the emotional-social area and perception of illness.

Key words: haemodialysis, quality of life, depression 